\title{
PHYTOPLAN COMMUNITY STRUCTURE IN Mex Bay, Alexandria, Egypt.
}

\section{Samiha M. Gharib}

National Institute of Oceanography and Fisheries, Alexandria, Egypt.

Key words: Phytoplankton, Diversity, Modelling

(Received may 20, 1998)

\section{ABSTRACT}

Dhytoplankton standing crop and diversity cycle in both Umum Drain and Mex 1 Bay were studied and discussed in relation to the most effective environmental physico-chemical parameters. The bay is affected by huge amounts of brackish waste water discharged from Umum Drain rich in nutrient salts which create dense algal growth. A total number of 162 phytoplankton taxa were recorded and characterised by different ecological affinities. Few species were responsible of the main bulk of the community, namely; Cyclotella meneghiniana, Nitzschia microcephala, Euglene caudate and Kirchneriella lunaris in Umum Drain and Skeletonema costatum, Cyclotella meneghiniana, Asterionella japonica and Prorocentrum micans in Mex Bay.

The phytoplankton standing crop attained an average of $0.71 \times 10^{6}$ and $0.94 \times 10^{6}$ units. $1^{-1}$ at the surface water of Umum Drain and Mex Bay respectively. The species diversity in Mex Bay showed irregular pattern ranging from 0.85 to 2.85 nats in the surface and from 0.68 to 3.10 nats in the near bottom layer.

The effect of the most ecological parameters on the standing crop and diversity index were stablished and discussed according to the regression models. 


\section{INTRODUCTION}

Mex Bay is one of the main fishing grounds in the west of Alexandria. It extends parallel to the coast line for about $7 \mathrm{Km}$, between El-Agamy head land and the western Harbour at longitude $29^{\circ} 50^{\circ} \mathrm{E}$ and latitude $31^{\circ} 10^{\circ} \mathrm{N}$. It has averages: width $3 \mathrm{Km}$, and total area about

$20 \mathrm{Km}^{2}$. The depth of water in the bay fluctuates between 1.5 and 15 metres. The bay receives a heavy load of waste water from industrial outfalls and also from Lake Maryut via Umum Drain (6-11.8 X $10^{6} \mathrm{~m}^{3} / \mathrm{day}$ ) (Said et al, 1991) through Mex pumping station. Umum canal drain is $45.8 \mathrm{Km}$ long with a bottom width of $20 \mathrm{~m}$. and an average depth of $3-4 \mathrm{~m}$.

The configuration of the bay, its major hydrography and chemical character have been studied by several authors; El-Wakeel and El-Sayed (1978); Mahmoud (1979 \& 1985); Aboul-Dahab and Halim (1986 \& 1988 a, 1988b) and El-Sarraf (1991). The distribution and ecology of the phytoplankton was studied by Dorgham et al (1987); El-Sherif (1989) and Samaan et al (1992), and the plankton of Umum Drain was studied also by Guerguess (1988). The characteristics of the water, phytoplankton and zooplankton population were also studied by Soliman and Gharib (1998).

The aim of the work is to study the spatial and temporal variations in the species composition of phytoplankton and the species diversity in order to evaluate the productivity of the bay water.

\section{MATERIAL AND METHODS}

Throughout the period from February to December, 1995, six trips were carried out in both Umum Drain and Mex Bay to collect phytoplankton samples from eight hydrographic stations (Fig.1). Sampling was made at surface water and near bottom layer using Ruttener sampler with a capacity of two litres.

The environmental conditions are studied by Soliman and Gharib (1998). Estimation of the phytoplankton standing crop was carried out by sedimentation 
method, counted and expressed as unit per litre. The following taxonomic references and publications were used for checking the species and for identification: Heurck (1896); Peragallo \& Peragallo (1 897-1908), Hustedt (1930); El-Nayal (1935 \& 1936); Bachmann (1936); Allen (1937) Huber-pestalozzi (1938), Cupp (1943); Khunnah (1967), Diversity index was estimated according to Shannon Weaver (1963) as follows:

$$
\mathrm{H}_{n}^{\mathrm{i}=1}=-\mathrm{S} \mathrm{P}_{\mathrm{i}} \ln \mathrm{P}_{\mathrm{i}}
$$

Where $P i=n / N$ is the proportion of the $i^{\text {th }}\left(n_{i}\right)$ species to the total number of phytoplankton $(\mathbb{N})$. Diversity index was expressed as nats.

The cluster analysis of Cormack (1971) is used to distinguish the groups of stations which behaved similarity on basis of the environmental conditions and abundance of phytoplankton groups. Correlation coefficient between biological (phytoplankton standing crop and diversity index) and physicochemical parameters were done of surface and near bottom layers $(n=48)$. Multiple regression equation at the confidence limit $95 \%(P=0.05)$ were calculated at the two layers to quantify the standing crop and diversity index in relation to the most correlative environmental factors. The stepwise analysis was performed using Number Cruncher Statistical System (NCSS) proposed by Hintze (1993) using a computer.

\section{RESULTS AND DISCUSSION}

\section{Phytoplankton Standing Crop}

\section{I-Species composition}

A total of 162 species, comprising 85 Bacillariophyceae, 31 chlorophyceae, 8 Euglenophyceae, 21 Cyanophyceae and 17 Dinophyceae, were collected from both Umum Drain and Mex Bay during the course of present study. Out of these, 4 and 60 species were specific to Umum Drain and Mex Bay, respectively, where as 98 species (48 diatoms, 25 Chlorophyceae, 15 Cyanophyceae, 6 Euglenophyceae and 4 Dinophyceae) were common to both Umum Drain and Mex Bay. Few of them were perennial and the most were seasonal. 
Diatoms contributed 50 and 83 species, Chlorophyceae 25 and 30 species, Cyanophyceae 16 and 20 species, Euglenophyceae 6 and 8 species and Dinophyceae 3 and 17 species, respectively, to a total species content of 100 in Umum Drain and 158 in Mex Bay. The fresh water forms distributed allover the bay and can be considered as "Hydrological indicators".

The number of species of the phytoplankton groups in Mex Bay in the different periods was summarized in Table (1); showed a gradual decrease, due to the increased amount of out falls discharged.

Tabel (2) it is obvious that, diatoms were more diversified in water salinity 30-38.5, while Dinophyceae were diversified in water salinity 20-30. Also. the diversity of Chlorophyceae, Cyanophyceae and Euglenophyceae in water salinity less than 10 may be attributed to the allochthonous fresh water forms.

\section{II- Spatial and bimonthly variations of the total phytoplankton and stations similarity}

\section{(Fig. 2,3 and 4)}

\section{1- Umum Drain}

Umum Drain represents the major source of waste water into the bay. It characterized by salinity $<10$, and a steady increase in the concentration of oxidizable organic matter (O.O.M) and ammonia (Mahomoud, 1985, Anon, 1989, Soliman and Gharib (1998). The community comprised mainly of brackish and fresh water forms transferred from Lake Maryout. The total average numbers standing crop wre $0.71 \times 10^{6}$ and $0.87 \times 10^{6}$ units. $1^{-1}$ in the surface and near bottom layers, respectively. These values were much higher than that recorded by Cuerguess (1988). Two peaks were recorded in the surface water; in February and June and other peaks were observed in the near bottom layer during February, April and June.

Bacillariophyceae were found to be the dominant group (average $0.46 \times 10^{6}$ units. $1^{-1}$ ) constituting from 13.4 to $89.5 \%$ to the total phytoplankton. 
Allochthonous diatoms (fresh-water forms) constituted the main component. Cyclotella meneghiniana was the major dominant species $(52.8 \%$ to the total diatoms), followed by Nitzschia microcephala (10.3\%). The first species occurred throughout _the year, rising to two peaks in June and August and the second rising in June.

Euglenophyceae showed a very irregular production, constituting from 0.11 to $75.2 \%$ to the total algae with an average of $0.14 \times 10^{6}$ cell. $1^{-1}$, mainly represented by Euglene caudata $(88.4 \%)$. It appeared all the year round with a peak in February (67.8\% to the total community). Euglena acus and Phacus longicauda showed different occurrence. Palmer (1969) noted that the genus Euglena, tops a list of sixty most tolerant genera to pollution. Munawar (1972) considered the genus as a biological indicator for organic pollution, high concentration of ammonia and organic matter, as agree with Nessim and Zaghloul (1991) and the present study.

Chlorophyceae constituted from 5.4 to $29.9 \%$ to the total phytoplankton, and represented mainly by Kirchneriella lunaris $(18.2 \%$ to the total Chlorophyceae) and dominated in April. Crucigenia quadrata (12.2\%) in December, Scenedesmus quadricauda (9.6\%) in Sc. bijugatus (6.7\%) in April and December.

Cyanophyceae never exceeded $8.7 \%$ to the total community. Dactylococcopsis irregularis was the most important, contributing $43.1 \%$ to the total cyanophytes with a high peak in April. Spirulina platensis (11.1\%) restricted from June to October, Oscillatoria limnelica (13.0\%) in February and December.

Dinoflagellates were observed in the near bottom layer during June and represented mainly by Peridinium conicum.

\section{2- Mex Bay}

Mex Bay showed a marked variability of phytoplankton standing crop in space andime as well as in community structure. Generally, the high concentration of nutrients create dense algal growth in the surface water than in the near bottom layer, this phenomenon is well known for coastal water in various parts of the 
world (Vollenweider, 1981, Rao and Mohanchand, 1988, Zaghloul 1994 a,b and Zaghloul 1995). The increasing frequency of algal blooms is the best indication of eutrophication as mentioned by Cruzado (1988). Water column stability tended to increase in June and August which reflect as an important factor for phytoplankton growth as mentioned by Raymont (1980) and gree with the results of Zaghloul (1995) in the Eastern Harbour.

Mex Bay sustained high standing crop of phytoplankton with averages $0.94 \times 10^{6}$ and $0.48 \times 10^{6}$ units. $1^{-1}$ in the surface and near bottom layers respectively. These values are much higher than that recorded by Samaan et al (1992) and El-Sherif (1989) and attributed to the increased drainage water which makes the bay as highly eutrophic region.

\section{February}

Water temperature reached $16^{\circ} \mathrm{C}$, the diluted water mass was dominated and nutrient concentrations were high (Soliman and Gharib (1998). The phytoplankton counts showed a marked distinct between surface and near bottom layers with 93 species. Brackish and fresh-water forms were dominant in front of the drain. Euglenophyceae formed $46 \%$ to the surface community with 7 species and dominated by Euglena caudata. Diatoms formed $41.8 \%$ with 50 species and represented mainly by Cyclotella meneghiniana, Skeletonema costatum and Asterionella japonica. Chlorophyceae and Cyanophyceae formed respectively 6.3 and $5.5 \%$ to the surface community (16 and 12 species).

Stations 1 and 2 which were more affected by drainage water had the greatest similarity level of $96 \%$ due to their combination with the lowest salinity and highest concentrations of nutrient salts as well as similar phytoplankton counts. Station 3 affected also by the drainage water showed similar properties to the former stations with level of $92 \%$.

\section{April}

Water temperature showed a slight increase accompanied by a rise in salinity. In consequence, the phytoplankton standing crop in the surface water 
showed its largest peak of the year, where the community included 97 species. Stations 4 and 6 were more fertile with density. The current extends westward along the coastline and transported the fertile water to the west (Gergis, 1979) as in station 4.

Diatoms were the main bulk of the community (85.7\%) with 54 species. Chaetoceros curvisetum and Skeletonema costatum were the dominant forms. Chlorophyceae formed a high peak at station 2 in which kirchneriella spp., Grucigenia quadrata and Scenedesmus dimorphtus formed the main bulk.

The dendrogram classification having a similarity level of $74 \%$ between stations 7 and 8 which were attained similar phytoplankton counts and a similarity of $67 \%$ between stations 4 and 5 in which salinity values and ammonia concentrations were nearly similar.

June

Water temperature increased remarkably with a distinct salinity stratification. A further progressive phytoplankton increase was observed in the near bottom layer. The community included 92 species and the bloom was seen to cover all the bay.

Diatoms (42 species) contributed $73.6 \%$ to the total community. As in April, Skeletonema costatum was leading. The species is indicator of eutrophication (Mihnea, 1985; Revellante and Gilmartin, 1985). Dinoflagellates comprised 14 species (19.5\%) with apeak at station 5 mainly from Prorocentrum micans. The species is tolerance to domestic wastes (Zaghloul, 1994a). A good association was found between the occurrence of S.costatum and Prorocentrum spp. as mentioned by Iwasaki (1979).

In the linkage dendrogram, stations 1 and 4 were combined with similar phytoplankton counts and had a similarity level of $94 \%$. Station 2 showed great similarity ( $84 \%)$ to the former stations due to its situation infront of the drain. 


\section{August}

Water temperature raised up to $29.1^{\circ} \mathrm{C}$ associated with higher salinity (over 38.5) in the northeast of the bay. The phytoplankton standing crop (87 species) was high and outstanding peak was observed at station 8. Diatoms (42 species) contributed $86.1 \%$ to the total standing crop, represented mainly by Cyclotella meneghiniana and Nitzschia longissima. Dinoflagellates ( 9 species) contributing $10.0 \%$ with Gessnerium mochimaensis dominant and Prorocentrum micans frequent.

Stations 4 and 5 had a similarity level of $92 \%$ and were characterized by high salinity values $(37 \%)$, similar nutrient concentrations as well as equal numbers of phytoplankton. While stations 1 and 2 with similarity of $89 \%$ attained lowest salinity and similar counts of phytoplankton where Cyclotella meneghiniana was the dominant in each.

\section{October}

Despite of a sharp drop in phytoplankton standing crop, the greatest numbers of species were recorded allover the year (107 species). Vertically, a sharp drop in numbers were observed. The north eastern part of the bay was more fertile accompanied with high nutrient concentrations, nitrate reached its maximum (Soliman and Gharib in press). Diatoms contributed $81.3 \%$ to the total standing crop (53 species), represented mainly by Cyclotella meneghiniana. Chlorophytes (24 species) ranked the second (15.7\%), mainly Scenedesmus spp.

Stations 1,2 and 7 which showed great similarity, were combined with the lowest value of salinity $(6 \%)$ and similar phytoplankton counts. The great similarity between stations 3 and 5 was due to the same salinity value (24\%) and the same phytoplankton counts.

\section{December}

A further temperature decrease was observed. Salinity was low inshore, increasing gradually offshore and the water column was stratified. The 
phytoplankton density was still low and the community was rich (100 species). Diatoms (54 species) contributed $58.4 \%$ to the total standing crop and dominated by Asterionella japonica. The species showed more susceptibility to the municipal wastes (Zaghloul, 1994a). Chlorophytes comprised 21 species (30.5\%), mainly restricted near the drain and dominated by Crucigenia spp. and scend. bijugatus. Cyanophytes comprised 12 species $(9.4 \%)$, mainly Oscillatoria limnetica and Dactylococcopsis irregularis, both restricted near the drain.

Station affinities delineated two groups, the first group showed great similarity between stations 5,8 and 6 , where they were characterized by equal salinity, concentrations of nutrient salts and phytoplankton counts. The leading species in this group was Asterionella japonica. The second group comprised stations 2 and 3 and showed highest phytoplankton counts. Cyclotella meneghiniana was the dominant species in the second group.

\section{III- Phytoplankton and water quality relationships}

Diatoms and Dinoflagellates were positively correlated with salinity, while the fresw hater groups showed negative correlations, this reflects the promoting effect of drainage water on algal growth. As a result of phytoplankton growth, standing crop was negatively correlated with water transparency $(r=-0.2)$. Significant positive correlation was found between $\mathrm{pH}$ values and the numerical standing crop $(\mathrm{r}=0.4)$. The positive correlation between oxidizable organic matter and each of ammonia and phosphate concentrations as a result of allochthonous and autochthonous sources and the negative one with salinity shows the drain water to be the major source of O.O.M in Mex Bay (allochtonous source). A positive correlation between O.O.M and phytoplankton $(r=-0.23 \& 0.63$ in surface and bottom layers respectively)and also between dissolved oxygen and phytoplankton ( $\mathrm{r}=.33 \quad \& 0.26)$. The negative correlation between phytoplankton standing crop and nitrate $(\mathrm{r}=-0.32)$ means that phytoplankton prefere $\mathrm{NO}_{3}$ rather than any other nitrogen form.

In the surface water, a strong positive correlations were existed between phosphate and each of Euglenophyceae $(r=0.37)$, Chlorophyceae $(r=0.61)$ and Cyanophyceae $(r=0.64)$, where it is negatively correlated with diatoms $(r=-0.33)$ 
and Dinoflagellates $(=-0.36)$. Although phosphorus was unlimiting factor, yet it is essential element for the growth of the dominant groups. In the near bottom layer, it was also showed positive correlation with the fresh water forms. Due to the high consumption by diatoms silicate showed negative correlation $(r=-0.29)$, but positive correlation with chlorophyceae and Cyanophyceae $(r=0.33, r=0.32)$.

Concerning the relation between phytoplankton standing crop (St. crop) and the environmental parameters, a series of statistical regression models were estimated. These models describe the dependence of standing crop on the most effective measured abiotic factors at both surface water $(S)$ and near bottom layer (B) as follows:

St. crop (S) units. $\mathrm{l}^{-1}=-31209 \mathrm{E}^{2}+571753 \mathrm{pH}-1654$ Transparency $-56649 \mathrm{PO}_{4}$ $(\mathrm{M} . \mathrm{R}=0.48)$

St. crop (B) units. $1^{-1}=-375105+108388$ O.O.M 133618 Dissolved oxygen $24470 \mathrm{NO}_{3}$ $+14057 \mathrm{SiO}_{4}-148657 \mathrm{PO}_{4}$ $(M . R=0.79)$

Phosphate was the most effective environmental factor controlling the phytoplankton standing crop at the two layers. $\mathrm{PH}$ values had a positive effect at the surface, while $0.0 . \mathrm{M}, \mathrm{NO}_{3}$, dissolved oxygen and $\mathrm{SiO}_{4}$ showed more effective in the near bottom layer comparison of observed and predicted values for the two layers (Fig 5) showed a small deviation which may be due to the interference of other, unmeasured physical and chemical variables not included in the model.

\section{Diversity Index}

\section{1- Diversity Cycle}

Generally, species diversity of phytoplankton in Umum Drain and Mex Bay showed irregular pattern. In Umum Drain, lowest values (1.08 nats in the surface and 0.93 nats in the near bottom layer) were recorded during April and June respectively. This accompanied with lowest numbers of species all over the year (16 and 14 species). The degree of dominance were 47 and $71 \%$ to the total community $\left(203 \times 10^{3} \& 1,361 \times 10^{3}\right.$ units. $1^{-1}$ respectively). The dominant species was Skeletonema costatum for the two layers of water. Highest values of diversity were 2.20 nats in the surface of December and 2.98 in the near bottom of April. 
This was met with species richness of 24 and 37 species and phytoplankton standing crop of $316 \times 10^{3}$ and $1,549 \times 10^{3}$ units. $1^{-1}$ respectively. Such increased diversity reflects the absence of distinct dominance of any particular species where the dominancy in December was shared by several species, particularly, Cyclotella meneghiniana (31\%), Crucigenia quadrata $(17 \%)$ and Scenedesmus quadricauda $(4.6 \%)$, while in -

April it shared by C. meneghiniana (19.5\%), Dactylocaccopsis irregulais $(18.1 \%)$ and Nitzschia microcephala $(8.0 \%)$.

In Mex Bay, species diversity was negatively correlated with phytoplankton standing crop $(r=-0.25$ and $r=-0.39$ in surface and near bottom layers respectively). The surface diversity index ranged between 0.85 nats (St.4, June) and 2.85 nats (St.7, December). This was met with species richness of 27 and 38 species and noticeable variations in the magnitude of phytoplankton numbers $\left(1,693 \times 10^{3} \& 263 \times 10^{3}\right.$ units. $1^{-1}$ respectively). The dominant species in June was Skeletonema costatum $(79 . \%$, while in December, the dominancy was shared by several species, as Cyclotella meneghiniana (18.2\%), Crucigenia quadrata (10.7\%) and Kirchneriella lunaris $(9.1 \%)$.

In the near bottom layer, diversity index showed wider range from 0.68 nats (St.6, June) and 3.10 nats (St.8, October). This was met with species richness of 23 and 33 species and phytoplankton standing crop of $755 \times 10^{3}$ and $28 \times 10^{3}$ units. $1^{-1}$ respectively. The low diversity was accompanied by higher frequency of only one species, Skeletonema costatum 88\%), while the high diversity was corresponded to the dominancy of Nitzschia sigma $(11 \%)$, N.seriata $(10 \%)$ and Cyclotella meneghiniana (6\%).

Simple equations confimed negative correlation between species diversity $(\mathrm{H})$ and the percentage frequency of the dominant species (D) at both surface ( $\mathrm{S}$ ) and near bottom layer (B) in Mex Bay as follows:

$$
\begin{gathered}
H(S)=3.036-2.439 \mathrm{D} \quad\left(\mathrm{r}^{2}=0.867\right) \\
\mathrm{H}(\mathrm{B})=3.226-2.784 \mathrm{D} \quad\left(\mathrm{r}^{2}=0.911\right)
\end{gathered}
$$

Figure (6) represents the relationship between diversity $(H)$ and the degree of dominance (D). 


\section{2- Diversity and habitat structure relationship}

Species composition of phytoplankton community and / or the dominance depend on the interaction between ecological, biological and evolutionary processes in the surrounding habitat (Margalef, (1978) and Hallegraeff \& Reid, (1986). So, the availability of resources is one of the most important ecological factors affecting species diversity. This was emphasized by numerous workers as Cosser, 1988, Abdalla et al, (1992) and Zaghloul, (1995.)

According to Soliman and Gharib (in press), Mex Bay receives a huge amount of waste water rich in nutrient salts, this creates eutrophication at times particularly spring and summer. At the surface water, species diversity was negatively correlated with water temperature

$(r=-0.51), 0.0 . \mathrm{M}$. ( $r=-0.32)$, salinity $(r=-0.21)$, but appeared positively correlated with transparency $(r=-0.26)$ and phosphate $(r=0.23)$. At the near bottom layer, it was also negatively correlated with water temperature $(r=-0.33), 0.0 . M$. $(r=-$ $0.35)$ and positively correlated with nitrite $(r=0.28)$.

The stepwise multiple regression equations describing the dependance of species diversity $(\mathrm{H})$ and the most effective environmental factors are: $\mathrm{H}(\mathrm{S})=3.008657-0.058459$ Temp. $+0.001776 \mathrm{SiO}_{4}-0.017908$ 0.0.M.

$$
(\mathrm{M} . \mathrm{R}=0.57)
$$

$\mathrm{H}(\mathrm{B})=2.119-0.0220 .0 . \mathrm{M}+0.136 \mathrm{NO}_{2}-0.003 \mathrm{SiO}_{4}-0.053 \mathrm{Terp} .+0.022 \mathrm{~S} \%$

$$
(M . R=0.57) \text {. }
$$

These models are adequate at a significant level of $95 \%(\mathrm{P}=0.05)$. From these equations, it appears that the effect of temperature, silicate and O.O.M. were pronounced in both two layers, while in the near bottom layer, the effect of nitrite and salinity was more clear. Comparison of the observed phytoplankton diversity to the models (Fig. 7) showed a small error to the interference of other factors.

In conclusion, the continuous land run off into the bay caused massive development of algal blooms and the coastal current allows such blooms to extend along the shore line and fresw hater forms were found as codominant with marine forms. A gradual deterioration of water quality creates on the long run nuisance 
and aesthetic problems in the recreational beaches. Accordingly, it is recommended that the waste water should be treated according to sanitary regulations before being discarded into the bay.

\section{REFERENCES}

Abdalla, R. R.; Y. Halim; W.L. Gergis and F.N. Assad, (1992). Phytoplankton diversity in the oligotrophic waters west of Alexandria (Egypt). Bull. Nat. Inst. Oceangr. and Fish. 18:73-84.

Aboul-Dahab, O. and Y. Halim, (1986). Impact of land-based sources on chromium species and concentrations in coastal water west of Alexandria Rapp. Comm. Int. Mer. Medit., 30(2):(P, 108).

Aboul-Dahab, O. and Y. Halim. (1988a). Chromium fluxes through Mex Bay inshore waters. Rapp. Comm. Int. mer. Medit., 31(2):(P, 33).

Aboul-Dahab, O. and Y. Halim. (1988b). Spatial distribution and speciation of tin compounds in sediments of Alexandria coastal belt. Rapp. Comm. Int. Mer. Medit. 3I(2):(P, 144).

Allen. W.E. (1937). Plankton Diatoms of the gulf of Califorina obtained by the G. Allan Hancok expedition of 1936. 3(4).

Anon. (1989). Coastal transport of pollutants along Alexandria coast, Egypt. Tech. Rep. 1.43 pp. Submitted to the Intergovernmental Oceanog. Comm., (IOC).

Bachmann, H. (1936). Phytoplankton from the Nile. Fisheries Research Directorate. Notes \& Mem., No. 22, Egypt. 2 PP.

Cosser, R., (1988). Macroinvertebrate community structure and chemistry of an organically polluted Greek in the south east Queenland. Aust. J. Mar. Fresh. Water. Res. 39:671-683. 
Cormack, R.M., (1971). A review of classification. J.R. Statist. Soc. Ser. A., 134:321-367.

Cupp, E.E. (1943). Marine plankton diatoms of the west coast of North America. Bull. Scripps. Inst. Oceanog. 5:1-238.

Gruzado, A., (1988). Eutrophication in the pelagic environment and its assessment. Bologna, Italy, 2-6 March (1987). Map. Technical Report Series No. 21:57-66.

Dorgham, M., M. El-Samra, M. TH. Moustafa, (1987). Phytoplankton in an area of multi-polluting factors west of Alexandria, Egypt. Qatar Univ. Sci., Bull., 7:393-419.

El- Nayal, A.A. (1935). Egyptian Fresw hater Algae. Bull. Fac. Sci. Cairo, No. 4. $106 \mathrm{pp}$.

El- Nayal, A.A. (1936). Contribution to our knowledge of the fresh water algae of Egypt. Bull. Fac. of Sci. Cairo, Part 1, No. 9.3IP.

El-Sarraf, W. M. (1991). Water quality of the Mediterranean coastal marine environment in front of Alexandria, Egypt. Bull. Nat. Inst. Oceanog. \& Fish., ARE, 17(1):25-30.

El-Sherif, Z. M. (1989). Distribution and ecology of phytoplankton in El-Mex Bay (Egypt). Bull. Inst. Oceanogr. Fish., ARE, 15(2):83-100.

El-Wakeel, S.K. and El-Sayed, M.Kh. (1978). The texture, mineraology and chemistry of bottom sediments and beach sands from the Alexandria region, Egypt. Mar. Geol., 27:137-160.

Gergis, M.A., (1979). The hydrographic characteristics and surface circulation of the Mediterranean coastal waters from Matrouh to Rosetta. In technical report No(2/1) on Fisheries investigations of the Sardine and other pelagic fish along the Egyptian Mediterranean coast. Inst. Oceanogr. \& Fish. Alex. Egypt 
Guerguss, S. K. (1988). Plankton of Lake Maryut outlet, west from Alexandria. Bull. Nat. Inst. Oceanogr.\& Fish., A R E 14(2):153-171.

Hallegraeff. G.M. and D.D. Reid, (1986). Phytoplankton species successions and their hydrological environments at a coastal station of Sydney. Aust. J. Mar. and Fresh-water. Res., 37:361-377.

Heurck, V.H. (1896). A treatise on the Diatomaceae. William Westey and Son, 28, Essex, Strand, W.C. 559PP.

Hintze, J. L., (1993). Number crunched statistical system (NCCS). Version 5.03 $5 / 1993$.

Huber-Pestalozzi, G. (1938). Das phytoplankton des Suss Wassers. I. Teule, Die Binnengewasser-Stuttgart $342 \mathrm{pp}$.

Hustedt, F. (1930).Die Kieselalgen Deutschlands. Oesterreichs und der Schweiz. In Rabenhorst kryptogamen Flora, 7(1-920), 542Fig.

Iwasaki, H. (1979). The physiological characteristics of neritic red tide flagellates. In: Taylor, D. and Seliger, H. (eds.) Toxic Dinoflagellate blooms, $2^{\text {nd }}$ Int. Conf. Elsevier, North Holland, New York, 95-100.

Khunnah, M.C. (1967). Chlorococcales, the Indian Council of Agricultural Research, New Delhi. Job Press Private Ltd., Kanpur 363 pp.

Mahmoud, Th. H. (1979). The effect of sewage discharge on the water quality of the coast of Alexandria. M.Sc. Thesis, Alexandria University, 135pp.

Mahmoud, Th. H. (1985). Phosphorus and nitrogen dynamics in the polluted coastal waters off Alexandria. Ph. D. Thesis, Alexandria University, $301 \mathrm{pp}$.

Margalef, R. (1978). Life form of phytoplankton as survival alternatives in an unstable environment. Oceano. Acta., 1:493-509. 
Mihnea, P.E. (1985). Effect of pollution on phytoplankton species. Rapp. Comm. Int. Mer. Medit., 29 (9):85-88.

Munawar, M., (1972). Ecological studies of Eugleninacea in certain polluted and unpolluted environments. J. Hydrobiologia., 39:307-320.

Nessim, R. B and F. A. Zaghloul, (1991). Nutrient and chlorophyll at Kayet Bey region (Alexandria). Proc. Symp. Mar. Chem. in the Arab Region, Suez, April, 1991, 7I-80.

Palmer, C.M. 1969. A composite rating of algae tolerating organic pollution. J. Phycol., 5:78-82.

Peragallo, H. and M. Peragallo, (1897-1908). Diatomees Marines de France et des Districts maritimes voisins. I.III (text and plates). I-491, Tempere Grez-Sur loing.

Rao, M.U and V. Mohanchand, (1988). Water quality characteristics and phytoplankton of polluted Visakhaptnam Harbour. Marine Environmental Research, 25:23-43.

Raymont, J.E.G. (1980). Plankton and productivity in the oceans. $2^{\text {nd }}$ Edition, Vol. 1, Phytoplankton Pergamon Press Oxford, NewYork, 489 pp.

Revelante, N. and Gilmartin, M. (1985). Possible phytoplankton species as indicators of eutrophication in the northerm Adriatic Sea. Rapp. Comm. Int. Mer. Medit., 29(9):89-91.

Said, M.A., El-Deek, M.S., Mahmoud, Th.H. and Shridah, M.A. (1991). Physicochemical characteristics of different water types of El-Mex Bay, Alexandria, Egypt. Bull. Nat. Inst. Oceanogr. Fish., ARE, 17(1):103-116. 
Samaan, A.A., Abdella, R.R. and Gergis, W.L. (1992). Phytoplankton population in relation to hydrographic conditions along the west-coast of Alexandria (Egypt). Bull. Nat. Inst. Oceanogr. Fish., ARE, 18:53-71.

Shannon, C.E., and W. Waever, (1963). The mathematical theory of communication. Univ. of Illinois. Press, Urbana.

Soliman, A.M., and S.M. Gharib. (1998). Water characteristics, phytoplankton and zooplankton population of El-Mex Bay region. Bull. Fac. Sci. Alex. in press.

Vollenweider, R.A. (1981). Eutrophication-algal problem. WHO water Quel. Bull., 6.

Zaghloul, F.A. (1994a). Phytoplankton dynamics in the Western Harbour of Alexandria, Egypt. Bull. Nat. Inst. Oceanogr. and Fish. Vol. 20(2):107-117.

Zaghloul, F.A. (1994b). Impact of pollution on phytoplankton in a coastal marine environmental. Bull. Nat. Inst. Oceanogr. and Fish. Vol. 20(2):205-221.

Zaghloul, F.A. (1995). Comparative study of phytoplankton production, composition and diversity index in the Eutrophic Eastern Harbour of Alexandria, Egypt. Bulletin of High Institute of Public Health, Vol. $25(3): 665-678$. 
$30^{\circ} 50^{\prime}$

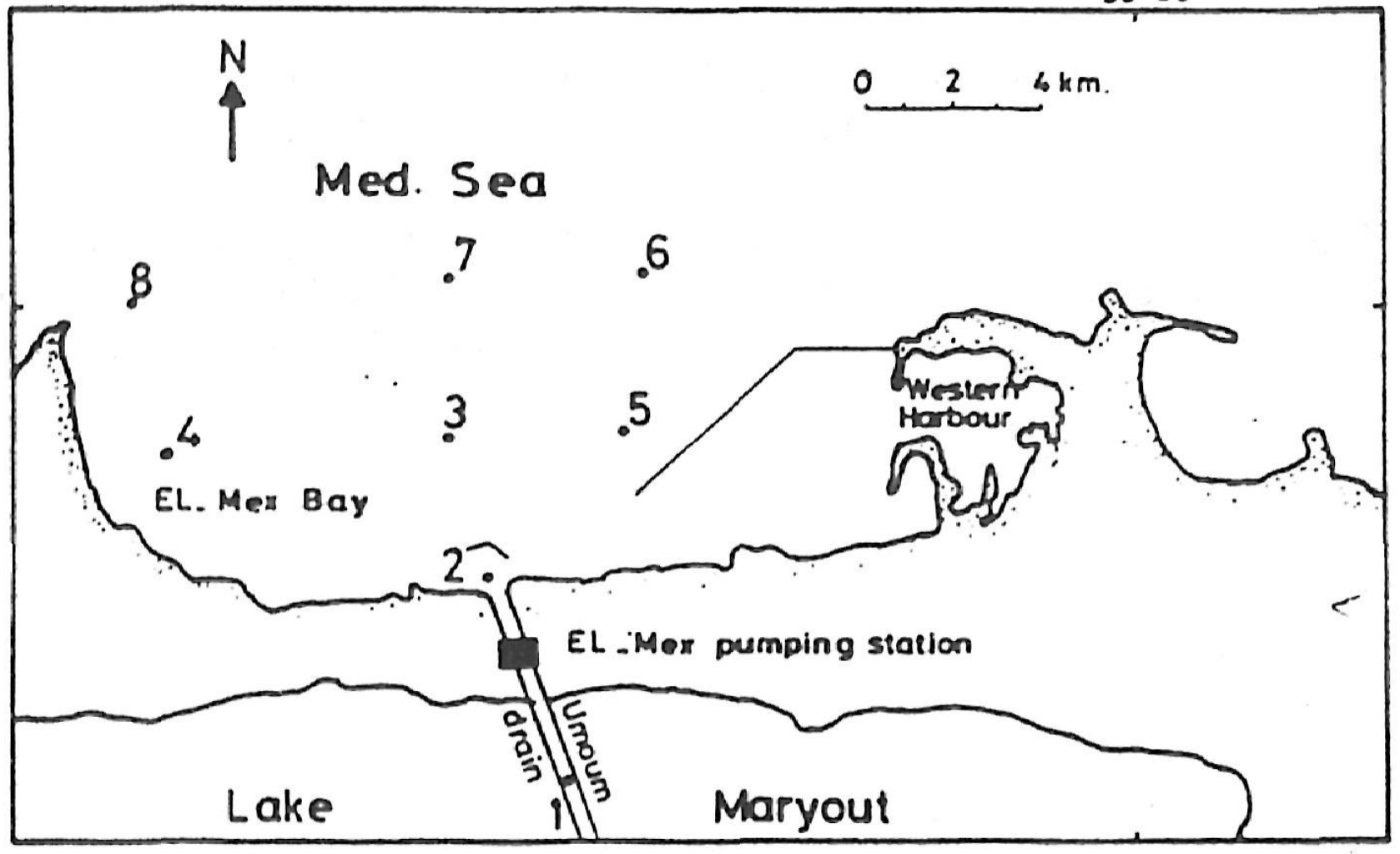

Fig. 1. Area of investigation and sampling sites. 


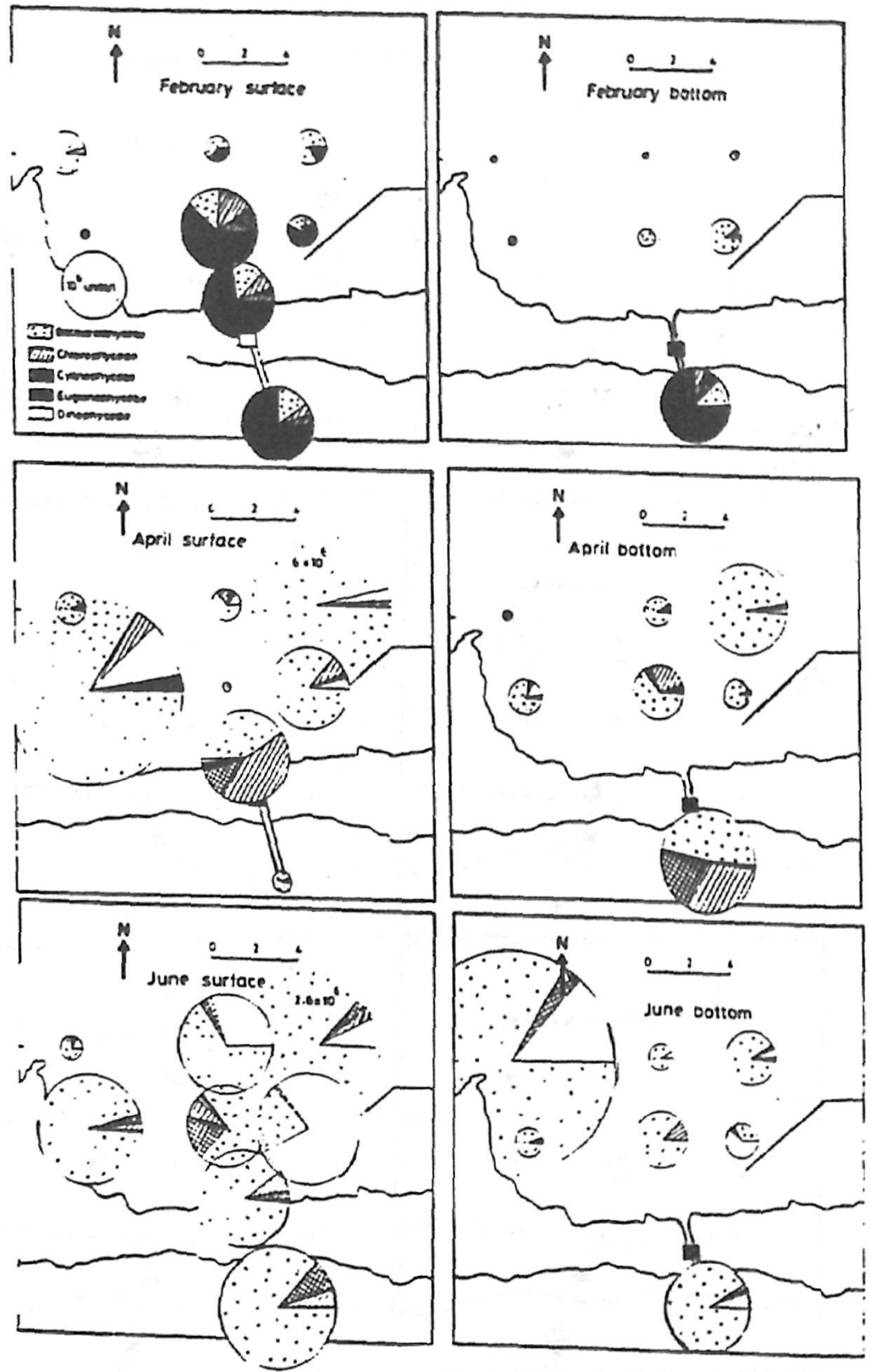

Fig. (2): Spatial and monthly abundance and percentage composition of phytoplankton in Mex Bay during February, April and June. 


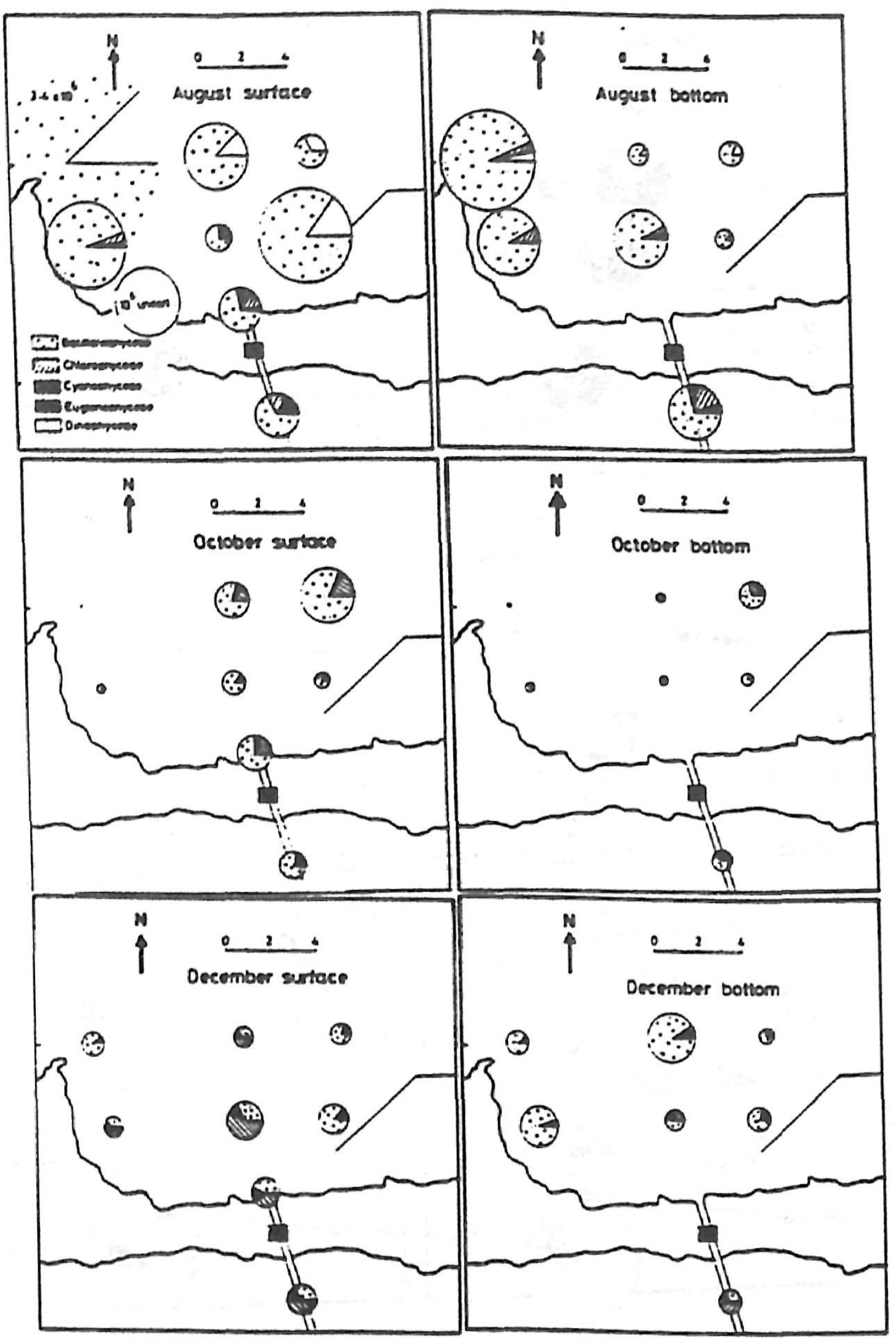

Fig. (3): Spatial and monthly abundance and percentage composition of phytoplankton in Mex Bay during August, October and December. 

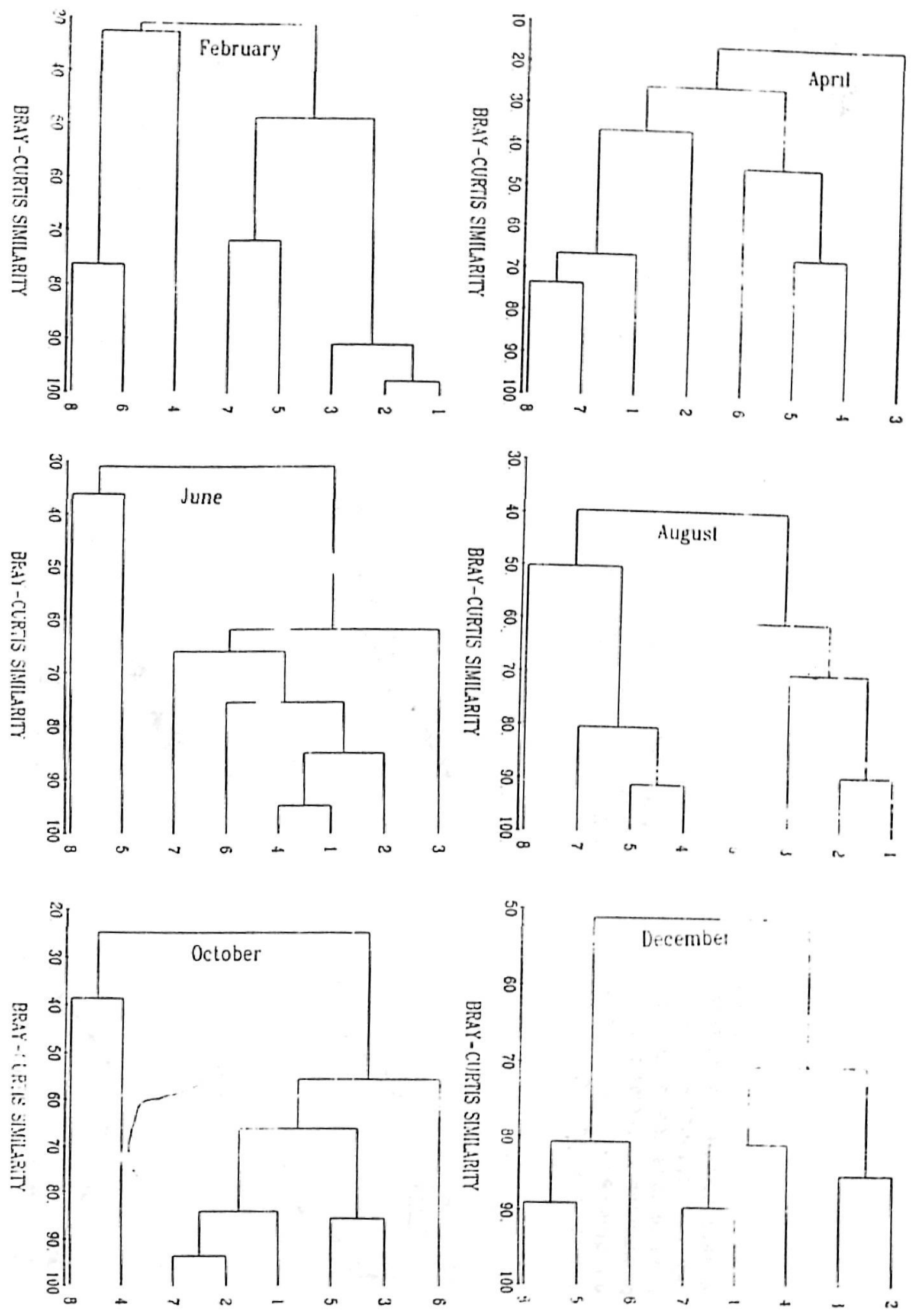

Fig. (4): Cluster dendrogram of stations in the surface water of Mex Bay based on the concentrations of environmental factors and abundance of phytoplarkton groups. 

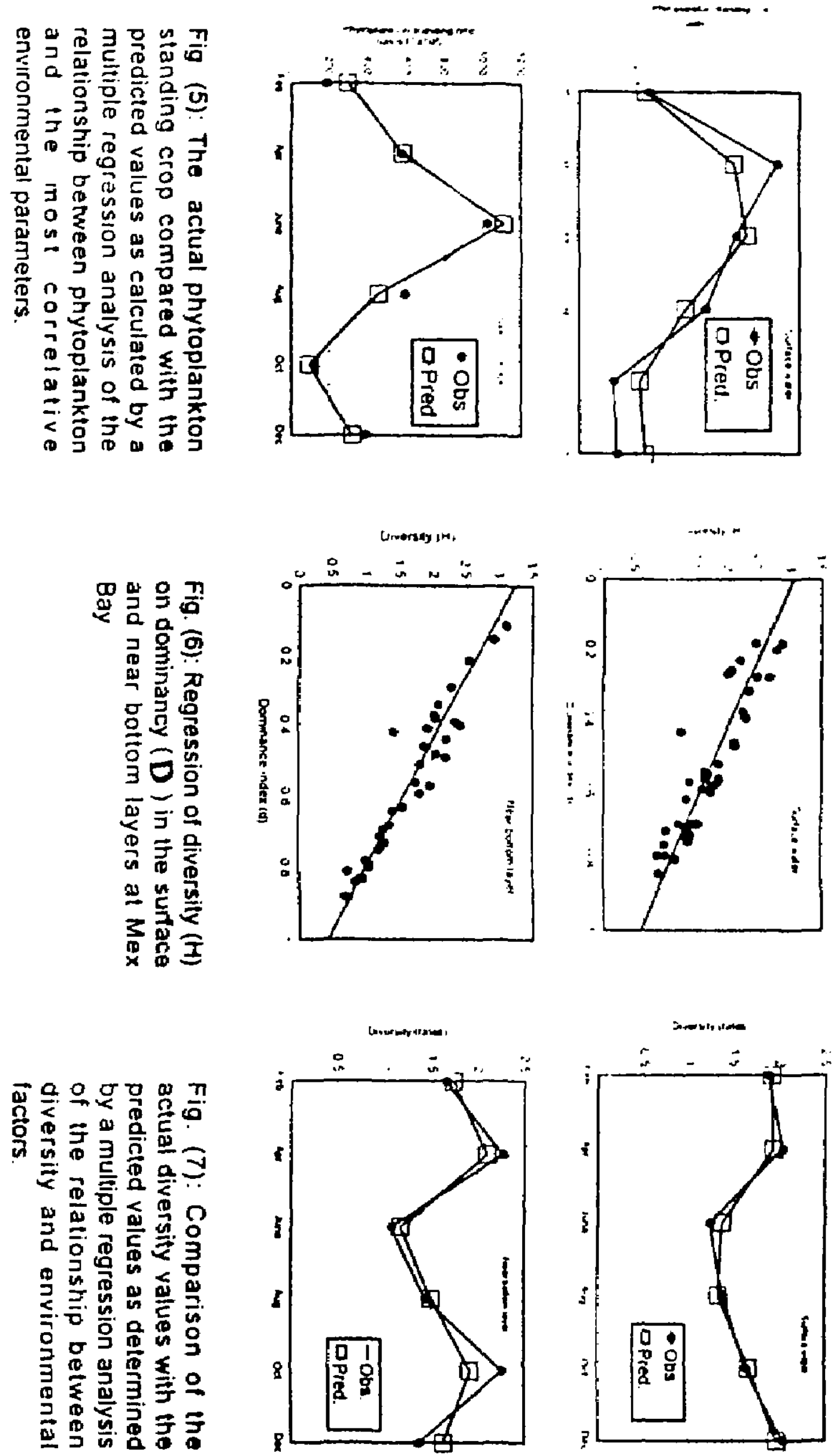
Table (1): Numbers of species of the phytoplankton groups recorded in the different periods in Mex Bay.

\begin{tabular}{|c|c|c|c|}
\hline $\begin{array}{c}\text { Reference and } \\
\text { period }\end{array}$ & \multicolumn{3}{|c|}{ Number of Species } \\
of study & \multicolumn{3}{|c|}{} \\
\hline Phytoplankton & Dorgham et all(1987) & El-Sherif (1989) & Present study \\
groups & $1982-1983$ & 1988 & 1995 \\
\hline Bacillariophycese & 119 & 83 & 83 \\
Chlorophyceae & 26 & 41 & 30 \\
Cyanophycese & 11 & 26 & 20 \\
Euglenophyceae & 4 & 4 & 8 \\
Dinophyceae & 50 & 5 & 17 \\
Total number of species & 210 & 159 & 158 \\
\hline
\end{tabular}

Table (2): Number of phytoplankton species recorded at different water types over the year.

\begin{tabular}{|l|ccccc|}
\hline Water Type & $\begin{array}{c}\text { Umum } \\
\text { Drain }\end{array}$ & \multicolumn{4}{|c|}{ Mex Bay } \\
& Salinity \\
\hline Phytoplankton groups & & $<10$ & $10-20$ & $20-30$ & $30-38.5$ \\
Bacillariophyceae & 50 & 43 & 49 & 62 & 67 \\
Dinophyctae & 3 & 3 & 7 & 15 & 14 \\
Chlorophyceae & 25 & 25 & 20 & 24 & 21 \\
Cyanophyceae & 16 & 17 & 15 & 16 & 12 \\
Euglenophyceae & 6 & 8 & 7 & 7 & 6 \\
Total & 100 & 96 & 98 & 124 & 120 \\
\hline
\end{tabular}




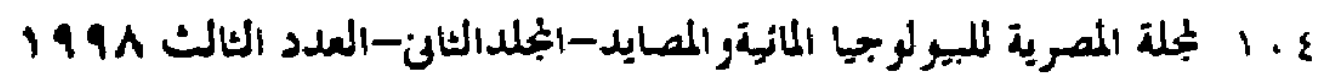

\section{تركية متمع العورالت اللباتية فل خحليج المكس الأسكندرية مييحة عبرد غريب} المعهد القومى لعلوم البحار والمصايد - الأنفوشى - الأبكندرية

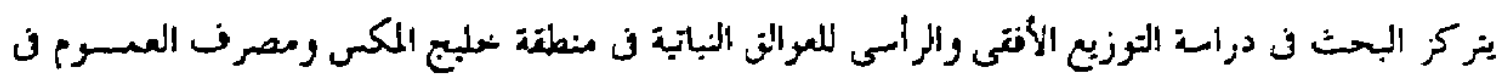
الفترز من نبراير حفى ديسمبر 1970 ودللك فل ضوء الظروف البيبة السائدة.

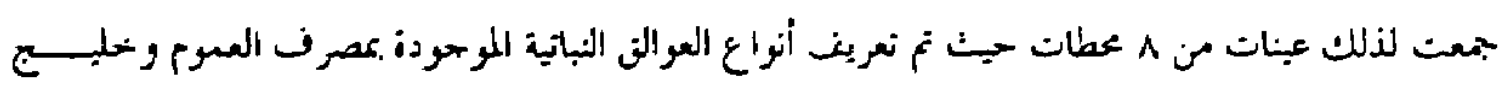

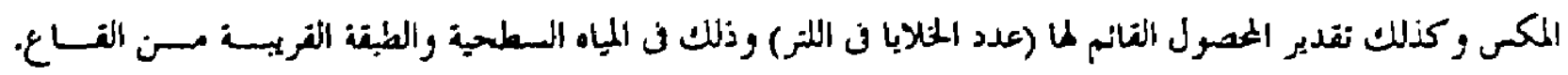

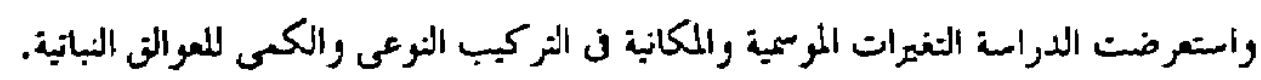

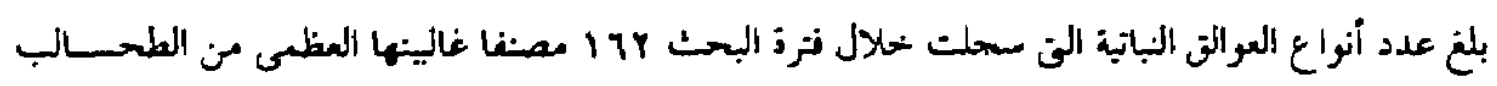

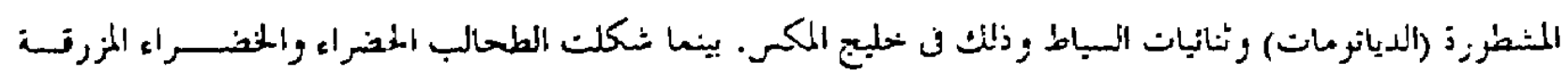

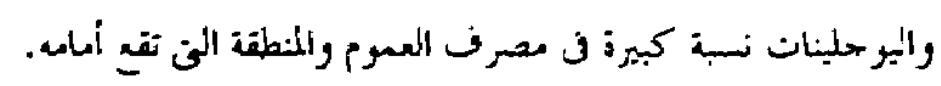

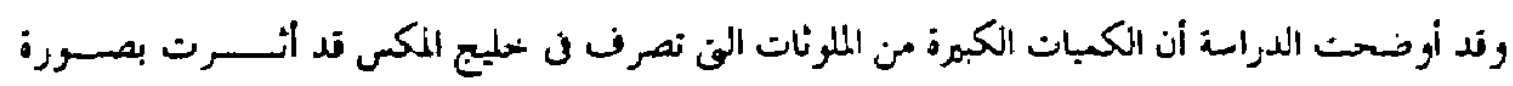

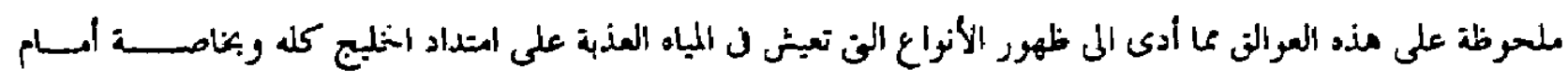

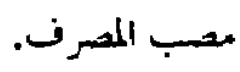

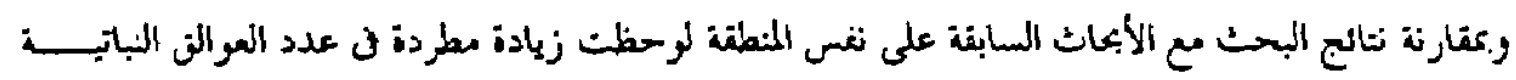

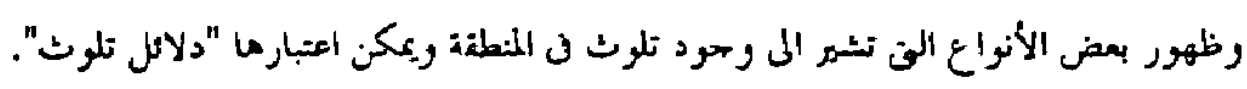

